\title{
Nitrous Oxide Emission and Crop Yield in Arable Soil Amended with Bottom Ash
}

\author{
Do-Yeong Hur ${ }^{1}$, Sung-Un Kim ${ }^{1,2}$, Hyeon-Cheol Park ${ }^{1}$, Keun-Ki Kim ${ }^{1}$, Hong-Ju Son ${ }^{1} \mathbb{D}_{\text {, Kwang-Min Lee }}{ }^{1} \mathbb{D}_{\text {, }}$ \\ Yu-Jin Kim ${ }^{1}$ (D) and Chang-Oh Hong ${ }^{1,2, *}$
}

1 Department of Life Science and Environmental Biochemistry, Pusan National University, Miryang 50463, Korea; hdy2953@pusan.ac.kr (D.-Y.H.); cross9279@pusna.ac.kr (S.-U.K.); hcpark@pusan.ac.kr (H.-C.P.); kkkim@pusan.ac.kr (K.-K.K.); shjoo@pusan.ac.kr (H.-J.S.); leekm@pusan.ac.kr (K.-M.L.); yjkim2020@pusan.ac.kr (Y.-J.K.)

2 Life and Industry Convergence Research Institute, Pusan National University, Miryang 50463, Korea

* Correspondence: soilchem@pusan.ac.kr; Tel.: +82-55-350-5548

Citation: Hur, D.-Y.; Kim, S.-U.; Park, H.-C.; Kim, K.-K.; Son, H.-J.; Lee, K.-M.; Kim, Y.-J.; Hong, C.-O. Nitrous Oxide Emission and Crop Yield in Arable Soil Amended with Bottom Ash. Agriculture 2021, 11, 1012. https://doi.org/10.3390/ agriculture11101012

Academic Editor: Claudio Marzadori

Received: 11 August 2021

Accepted: 12 October 2021

Published: 16 October 202

Publisher's Note: MDPI stays neutral with regard to jurisdictional claims in published maps and institutional affiliations.

Copyright: (c) 2021 by the authors. Licensee MDPI, Basel, Switzerland. This article is an open access article distributed under the terms and conditions of the Creative Commons Attribution (CC BY) license (https:// creativecommons.org/licenses/by/ $4.0 /)$

\begin{abstract}
Bottom ash (BA), a byproduct of coal combustion from electric power plants with a porous surface texture and high $\mathrm{pH}$, may influence the physical and chemical properties of upland arable soil associated with nitrous oxide $\left(\mathrm{N}_{2} \mathrm{O}\right)$ emission from upland soil. This study evaluated the use of BA in mitigating $\mathrm{N}_{2} \mathrm{O}$ emissions from upland arable soil and increasing the crop yield. In a field experiment, $\mathrm{N}_{2} \mathrm{O}$ emitted from the soil was monitored weekly in a closed chamber over a

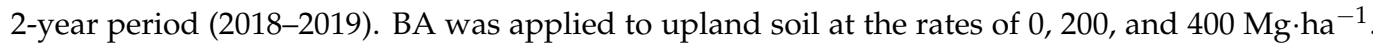
Cumulative $\mathrm{N}_{2} \mathrm{O}$ emission significantly decreased with increasing BA application rate; it decreased by $55 \%$ with a BA application rate of $400 \mathrm{Mg} \cdot \mathrm{ha}^{-1}$ compared with the control. Yield-scaled $\mathrm{N}_{2} \mathrm{O}$ emission decreased with increasing BA application rates of up to $200 \mathrm{Mg} \cdot \mathrm{ha}^{-1}$. Water-filled pore spaces (WFPS) were $70.2 \%, 52.9 \%$, and $45.3 \%$ at the rates of 0,200 , and $400 \mathrm{Mg}^{\circ} \mathrm{ha}^{-1}$, respectively, during the growing season. For economic viability and environmental conservation, we suggest that BA application at a rate of $200 \mathrm{Mg} \cdot \mathrm{ha}^{-1}$ reduces $\mathrm{N}_{2} \mathrm{O}$ emissions per unit of crop production.
\end{abstract}

Keywords: bottom ash; nitrous oxide; yield-scaled nitrous oxide emission

\section{Introduction}

Nitrous oxide $\left(\mathrm{N}_{2} \mathrm{O}\right)$ has 298-fold higher global warming potential than carbon dioxide $\left(\mathrm{CO}_{2}\right)$ over a 100 -year time horizon, contributing up to $6 \%$ of global warming [1,2]. Agricultural soils are the primary source of global anthropogenic $\mathrm{N}_{2} \mathrm{O}$ emissions, accounting for approximately $60 \%$ of the total $\mathrm{N}_{2} \mathrm{O}$ emissions [3], primarily owing to the application of synthetic nitrogen $(\mathrm{N})$ fertilizers and manures.

$\mathrm{N}_{2} \mathrm{O}$ is mainly produced as a result of microbial nitrification and denitrification in soils. Although nitrification requires $\mathrm{O}_{2}$, denitrification relies on its absence or limitation and is attributed to anoxic conditions. Water-filled pore spaces (WFPSs) of soils can be an indicator of the activity of aerobic and anaerobic microorganisms. Here, higher WFPS values indicate that more air replaced by water in pores, thus removing $\mathrm{O}_{2}$ from the soil. Changes in WFPS value comprise an important factor influencing $\mathrm{N}_{2} \mathrm{O}$ emissions from arable soils [4-7]. Nitrification that requires $\mathrm{NH}_{4}{ }^{+}$as an inorganic $\mathrm{N}$ substrate for aerobic respiration is the predominant process of $\mathrm{N}_{2} \mathrm{O}$ production from soils with a WFPS value of $<60 \%$. Conversely, denitrification that requires $\mathrm{NO}_{3}{ }^{-}$as an alternative electron acceptor for anaerobic respiration is a predominant process of $\mathrm{N}_{2} \mathrm{O}$ production from soils with a WFPS value of $>60 \%$ [6,8-12]. $\mathrm{N}_{2} \mathrm{O}$ emissions increase dramatically when both processes occur simultaneously as the soil WFPS value increases to almost $60 \%$ [13]. Soil pH is considered a critical factor for controlling various chemical and biological soil properties. Furthermore, soil $\mathrm{pH}$ has a significant effect on microbial processes responsible for the production and consumption of $\mathrm{N}_{2} \mathrm{O}$ in soils [14]. Primarily, the last step of denitrification $\left(\mathrm{N}_{2} \mathrm{O} \rightarrow \mathrm{N}_{2}\right)$ 
is strongly controlled by soil $\mathrm{pH}$. The reduction of $\mathrm{N}_{2} \mathrm{O}$ to $\mathrm{N}_{2}$ linearly increases with increasing soil $\mathrm{pH}[15,16]$. In addition, adjustment of the soil $\mathrm{pH}$ increases the abundance of $\mathrm{N}_{2} \mathrm{O}$ reductase genes (NosZ) at high $\mathrm{pH}$ values and decreases soil $\mathrm{N}_{2} \mathrm{O}$ emissions [17].

Coal ash is a byproduct of coal combustion in electric power plants. In 2020, more than 10 million tons of coal ash were generated globally, which are associated with storage, processing, and reclamation costs as well as near saturation of coal-fired power plants [18]. Coal ash is categorized into fly ash (FA) and bottom ash (BA) based on particle size. The recycling rate of $\mathrm{FA}$, a concrete additive and raw cement material or mixture, is $64 \%$ of the total FA recycle amount. Of the total BA, $37 \%$ is recycled as a concrete additive, and the remaining $60 \%$ is used as landfill in the Republic of Korea [19].

BA is larger and more irregular than FA and contains pores and cavities [20], has alkalinity close to $\mathrm{pH} 9$, and primarily comprises silicate $\left(\mathrm{SiO}_{2}\right)$, aluminum oxide $\left(\mathrm{Al}_{2} \mathrm{O}_{3}\right)$, and iron oxide $\left(\mathrm{Fe}_{2} \mathrm{O}_{3}\right)$ [21,22]. Albuquerque [23] reported that $\mathrm{BA}$ has highly available nutrients that can be applied to the soils to reverse nutrient depletion, and BA properties improve soil quality by increasing soil aeration [23]. Several studies have reported that using BA for soil amendment improves crop productivity without heavy metal toxicity [24-26].

The application of BA, which is porous and alkaline and adds plant nutrients to the arable soil, may change the physical and chemical properties of the soil, such as WFPS value, soil $\mathrm{pH}$, and nutrient supply that influence the $\mathrm{N}_{2} \mathrm{O}$ emission and crop yield. Based on previous studies $[7,13,15-17,23-26]$, this study presents three hypotheses: (1) the application of porous BA decreases the bulk density and WFPS value of soil to make soil conditions unfavorable for microorganisms associated with $\mathrm{N}_{2} \mathrm{O}$-production processes, such as nitrification and denitrification; (2) applying alkaline BA increases soil $\mathrm{pH}$, promotes reduction of $\mathrm{N}_{2} \mathrm{O}$ to $\mathrm{N}_{2}$, and decreases $\mathrm{N}_{2} \mathrm{O}$ emission; and (3) BA containing various elements provides available nutrients for plant growth and increases crop yield. Therefore, this study was conducted to evaluate the effects of BA application on mitigating $\mathrm{N}_{2} \mathrm{O}$ emission and increasing crop yield in upland soil within a radish-maize cropping system for 2 consecutive years.

\section{Materials and Methods}

\subsection{Experimental Site}

A field experiment was performed on arable soil located in Cheonghak-ri, Samrangjineup, Miryang, Gyeongnam Province, South Korea ( $35^{\circ} 26^{\prime} 59.9^{\prime \prime}$ N, $128^{\circ} 48^{\prime} 29.6^{\prime \prime}$ E). Single cropping of paddy rice cultivation was performed in the study site for approximately 10 consecutive years before the experiment. The experimental field was drained on 1 September 2017, for harvesting rice, which then remained drained throughout the experimental period. The study was conducted over 2 years: from April 2018 to March 2019 and from April 2019 to March 2020 for Years 1 and 2, respectively. Rotational cultivation of radish (Raphanus sativa L.) and corn (Zea mays L.) was performed in upland soil.

The average mean temperature and rainfall for the experimental period were $14.1{ }^{\circ} \mathrm{C}$ and $1259 \mathrm{~mm}$, respectively. The soil belongs to the Chilgok series (fine loamy, mixed, mesic family of Anthraquic Hapludalfs) and is well drained with a 2\% slope. The specific physical and chemical properties of the study soil are summarized in Table 1.

Table 1. Chemical and physical properties of studied soil $(n=3)$.

\begin{tabular}{|c|c|c|c|c|c|c|c|c|}
\hline $\begin{array}{c}\mathrm{Ph} \\
\left(1: 5 \mathrm{H}_{2} \mathrm{O}\right)\end{array}$ & $\begin{array}{c}\text { Electrical } \\
\text { Conductivity } \\
\left(\mathrm{ds} \cdot \mathrm{m}^{-1}\right)\end{array}$ & $\begin{array}{c}\text { Bulk } \\
\text { Density } \\
\left(\mathrm{g} \cdot \mathrm{cm}^{-3}\right)\end{array}$ & $\begin{array}{c}\text { Organic } \\
\text { Matter } \\
\left(\mathrm{g} \cdot \mathbf{k g}^{-1}\right)\end{array}$ & $\begin{array}{c}\text { Total } \\
\text { Nitrogen } \\
\left(\mathrm{g} \cdot \mathrm{kg}^{-1}\right)\end{array}$ & $\begin{array}{l}\text { Available } \\
\text { Phosphate } \\
\left(\mathrm{mg} \cdot \mathrm{kg}^{-1}\right)\end{array}$ & $\begin{array}{c}\mathrm{NH}_{4} \\
\left(\mathrm{mg} \cdot \mathrm{kg}^{-1}\right)\end{array}$ & $\begin{array}{c}\mathrm{NO}_{3} \\
\left(\mathrm{mg} \cdot \mathrm{kg}^{-1}\right)\end{array}$ & $\begin{array}{c}\text { Soil } \\
\text { Texture }\end{array}$ \\
\hline $5.47 \pm 0.25$ & $0.35 \pm 0.15$ & $1.26 \pm 0.12$ & $16.4 \pm 0.18$ & $1.05 \pm 0.15$ & $215 \pm 20$ & $5.1 \pm 0.14$ & $2.9 \pm 0.12$ & Silt loam \\
\hline
\end{tabular}




\subsection{Characterization of $B A$}

The BA used in this study was a byproduct of the coal-fired power plant from Korea South-East Power Co., Ltd. in Yeongheung, Republic of Korea. The BA was produced at a high temperature of approximately $1200^{\circ} \mathrm{C}$. Expanded X-ray diffraction (XRD) pattern analysis was performed to characterize the BA crystal structures as shown in Figure 1a. The surface morphology of BA and its physical and chemical properties are shown in Figure $1 \mathrm{~b}$ and Table 2, respectively. BA had a pH of 9.3 , total carbon of $6.6 \mathrm{~g} \cdot \mathrm{kg}^{-1}$ and total nitrogen of $0.9 \mathrm{~g} \cdot \mathrm{kg}^{-1}$. It was porous ( $58 \%$ porosity) and had a large surface area $\left(10.1 \mathrm{~m}^{2} \cdot \mathrm{g}^{-1}\right)$.
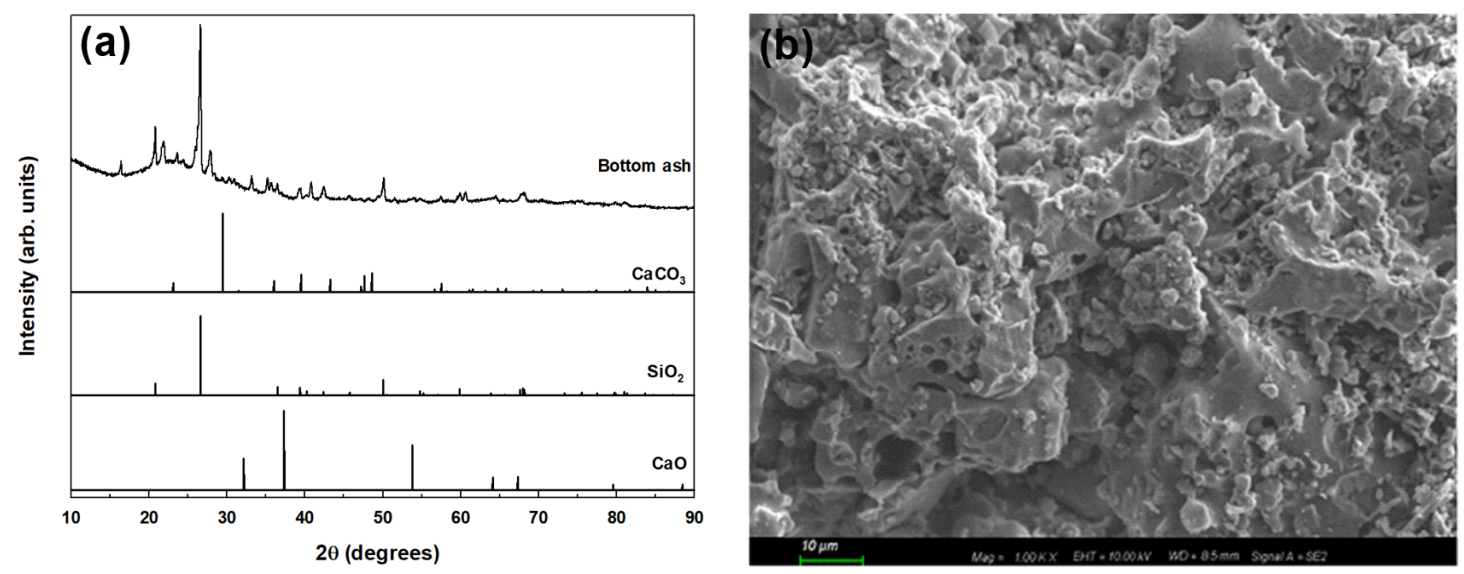

Figure 1. Expanded X-ray diffraction patterns (a) and surface morphology of bottom ash analyzed by SEM-EDS (b) used in this study.

Table 2. Chemical and physical properties of bottom ash used in this study $(n=3)$.

\begin{tabular}{|c|c|c|c|c|c|c|c|c|c|}
\hline $\begin{array}{c}\mathrm{pH} \\
(1: 5, \mathrm{KCl})\end{array}$ & $\begin{array}{c}\text { Electrical } \\
\text { Conductivity } \\
\left(\mathrm{dS} \cdot \mathrm{m}^{-1}\right)\end{array}$ & $\begin{array}{c}\text { Total } \\
\text { Carbon } \\
\left(\mathrm{g} \cdot \mathbf{k g}^{-1}\right)\end{array}$ & $\begin{array}{c}\text { Total } \\
\text { Nitrogen } \\
\left(\mathrm{g} \cdot \mathbf{k g}^{-1}\right)\end{array}$ & $\begin{array}{c}\text { Total Phos- } \\
\text { phorus } \\
\left(\mathrm{mg} \cdot \mathrm{kg}^{-1}\right)\end{array}$ & $\begin{array}{c}\mathrm{SiO}_{2} \\
(\%)\end{array}$ & $\begin{array}{c}\mathrm{CaCO}_{3} \\
(\%)\end{array}$ & $\begin{array}{c}\mathrm{CaO} \\
(\%)\end{array}$ & $\begin{array}{c}\text { Surface } \\
\text { Area } \\
\left(\mathrm{m}^{2} \cdot \mathrm{g}^{-1}\right)\end{array}$ & $\begin{array}{c}\text { Porosity } \\
(\%)\end{array}$ \\
\hline $9.3 \pm 0.19$ & $1.4 \pm 0.09$ & $6.6 \pm 0.4$ & $0.9 \pm 0.06$ & $130 \pm 17$ & $60 \pm 1.4$ & $39 \pm 0.9$ & $1 \pm 0.06$ & $10.1 \pm 0.12$ & $58 \pm 3.4$ \\
\hline
\end{tabular}

Silicate $\left(\mathrm{SiO}_{2}\right)$ and calcium carbonate $\left(\mathrm{CaCO}_{3}\right)$ showed distinct characteristic peaks, indicating high purity and crystallinity. However, calcium oxide $(\mathrm{CaO})$ showed several weak characteristic peaks. As shown during XRD pattern analysis, the relative percentages of $\mathrm{SiO}_{2}, \mathrm{CaCO}_{3}$, and $\mathrm{CaO}$ were $60 \%, 39 \%$, and $1 \%$, respectively.

\subsection{Experimental Design and Crop Management}

The BA was applied at the rates of 0,200 , and $400 \mathrm{Mg} \cdot \mathrm{ha}^{-1}$ to the experimental plots before crop cultivation on 1 April 2018. In total, 12 plots ( $3 \mathrm{~m} \times 4 \mathrm{~m}$ for each plot) were arranged in a randomized complete block design with four replicates. First, radish seeds were sown and then maize seeds. Radish seeds were sown and harvested on 30 March and 29 May 2018, and 1 April and 21 May 2019, respectively. Maize was planted and harvested on 29 May and 18 September 2018, and 22 May and 28 August 2019. Urea, fused phosphate, and potassium chloride were applied at rates of $\mathrm{N}-\mathrm{P}_{2} \mathrm{O}_{5}-\mathrm{K}_{2} \mathrm{O}=42-21-40 \mathrm{~kg}$ and $93-35-74 \mathrm{~kg} \mathrm{ha}^{-1}$ for radish and maize at base fertilizer application, respectively. Additional fertilizers such as urea and potassium chloride were applied at the rates of 74-0-40 and 93-0-0 $\mathrm{kg} \mathrm{ha}^{-1}$ for radish and maize, respectively. Base fertilizer application for radish and maize was conducted on 30 March and 29 May 2018, for Year 1 and on 1 April and 22 May 2019, for Year 2, respectively. Additional fertilizers for radish and maize were top-dressed on 1 May and 1 August 2018, for Year 1 and 13 May and 22 June 2019, for Year 2, respectively. BA and chemical fertilizers were spread on the soil surface and mixed into the soil using a rototiller to a depth of approximately $20 \mathrm{~cm}$. 


\section{4. $\mathrm{N}_{2} \mathrm{O}$ Emission Measurements}

A closed chamber method [27] was used to measure $\mathrm{N}_{2} \mathrm{O}$ emission from soil. Static PVC column chambers (headspace; $10.8 \mathrm{~L}, 25 \mathrm{~cm}$ diameter $\times 22 \mathrm{~cm}$ height) were placed at the center of each plot on 18 March 2018. The collar was placed between crops (radish and maize), and crops were not planted inside the chamber. All weeds that grew inside the chamber were removed during the experimental period. After 2 weeks of acclimation, the collar was closed with a fitted lid and air vent and rubber septa to collect gas samples. The plants grown inside the chamber were removed during the experimental period. Gas samples were collected using 30-mL syringes at 0,20 , and $40 \mathrm{~min}$ after covering the lid between 10:00 and 12:00 $\mathrm{h}$ throughout the year-long study period. Gas samples were collected once a week during the growing season of radish and maize, twice a week at special events, such as chemical fertilizer application and heavy rainfall, and once every 2 weeks during the fallow season. Gas sampling was performed throughout the study period from April 2018 to March 2020. The temperature in the chamber during gas sampling was measured using a portable thermometer (WT-1, Elitech, London, UK). The concentration of $\mathrm{N}_{2} \mathrm{O}$ was analyzed using a gas chromatograph-mass spectrophotometer (GC-MS QP2020, Shimadzu, Kyoto, Japan). $\mathrm{N}_{2} \mathrm{O}$ fluxes were calculated based on the slope of the linear increase in concentration during the chamber-closure period.

The $\mathrm{N}_{2} \mathrm{O}$ flux was calculated using the following formula:

$$
\mathrm{N}_{2} \mathrm{O} \text { flux }\left(\mathrm{g}^{\mathrm{h}} \mathrm{ha}^{-1} \cdot \mathrm{day}^{-1}\right)=\rho \times(V / A) \times(\Delta c / \Delta t) \times(273 / T+273) \times k \times a
$$

where $\rho$ is the gas density of $\mathrm{N}_{2} \mathrm{O}\left(\mathrm{g} \cdot \mathrm{m}^{-3}\right), V$ is the volume of the chamber $\left(\mathrm{m}^{3}\right), A$ is the soil area covered by the chamber $\left(\mathrm{m}^{2}\right), \Delta c / \Delta t$ is the rate of change in gas concentration in the chamber $\left(\mathrm{g} \cdot \mathrm{m}^{-3} \cdot \mathrm{min}^{-1}\right), T$ is the average temperature in the chamber $\left({ }^{\circ} \mathrm{C}\right), k$ is the time conversion coefficient $\left(\mathrm{min} \cdot \mathrm{day}^{-1}\right)$, and $a\left(10,000 \mathrm{~m}^{2} \cdot \mathrm{ha}^{-1}\right)$ is the area conversion coefficient.

Cumulative $\mathrm{N}_{2} \mathrm{O}$ emission was calculated as follows $\left(\mathrm{kg} \cdot \mathrm{N}_{2} \mathrm{O} \cdot \mathrm{ha}{ }^{-1}\right)$ :

$$
\text { Cumulative } \mathrm{N}_{2} \mathrm{O} \text { emission }\left(\mathrm{kg} \cdot \mathrm{ha}^{-1}\right)=\sum\left(\frac{F_{i}+F_{i+1}}{2}\right) \times\left(t_{i+1}-t_{i}\right)
$$

where $F$ represents the $\mathrm{N}_{2} \mathrm{O}$ flux $\left(\mathrm{g} \cdot \mathrm{N}_{2} \mathrm{O} \cdot \mathrm{ha}^{-1} \cdot\right.$ day $\left.^{-1}\right), i$ is the $i$ th measurement, and $\left(t_{i+1}-t_{i}\right)$ is the number of days between two adjacent measurements.

Yield-scaled $\mathrm{N}_{2} \mathrm{O}$ emission was calculated as follows [28]:

Yield-scaled $\mathrm{N}_{2} \mathrm{O}$ emission $\left(\mathrm{kg} \cdot \mathrm{N}_{2} \mathrm{O} \cdot \mathrm{Mg}\right)=$ cumulative $\mathrm{N}_{2} \mathrm{O}$ emission $\left(\mathrm{kg} \cdot \mathrm{ha}^{-1}\right) /$ crop yield $\left(\mathrm{Mg} \cdot \mathrm{ha}^{-1}\right)$.

\subsection{Soil Sampling and Analysis}

In each plot, soil sampling was performed before starting the experiment, after base and additional fertilizer applications, and after crop harvesting in the radish and maize growing season. Samples of the soil layers at $0-15 \mathrm{~cm}$ depth were collected using a hand auger ( $5 \mathrm{~cm}$ diameter) and a core sampler $\left(100 \mathrm{~cm}^{3}\right)$ to measure soil bulk density. Samples were then air-dried, passed through a $2 \mathrm{~mm}$ sieve, and kept in a plastic zipper bag for chemical analysis. Soil pH and EC were measured in a 1:5 soil:distilled water suspension using a $\mathrm{pH}$ and electrical conductivity meter (Orion Star A215, Thermo Scientific Orion, Mansfield, TX, USA). Organic matter content was analyzed using the Walkley and Black method [29], total nitrogen was analyzed using the Kjeldahl method, and available phosphorus was analyzed using the Lancaster method ( $5 \mathrm{~g}$ soil was extracted with $20 \mathrm{~mL}$ of

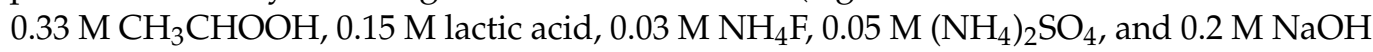
at a $\mathrm{pH}$ of 4.25) [30]. Analysis of soil inorganic nitrogen content was performed by adding $25 \mathrm{~mL}$ of $2 \mathrm{M} \mathrm{KCl}$ to $5 \mathrm{~g}$ of dry soil samples and shaking for $30 \mathrm{~min}$, after which sample solutions were filtered using Whatman No. 2 filter paper. Ammonium nitrogen $\left(\mathrm{NH}_{4}{ }^{+}\right)$ was measured using the indophenol-blue colorimetric method [31], and nitrate-nitrogen $\left(\mathrm{NO}_{3}{ }^{-}\right)$was measured using the brucine method [32]. 
Soil temperature and moisture at $10 \mathrm{~cm}$ soil depth were measured for each treatment at $3 \mathrm{~h}$ intervals using sensors (5TE Water Content, Temperature, and Electrical Conductivity, Decagon Devices, Inc., Pullman, WA, USA). Weather data, such as daily average temperature and precipitation during the experimental period were obtained from the local weather observation data (Aanderaa, Automatic weather station, xylem, Bergen, Norway) of the Korean Meteorological Administration (latitude: $35^{\circ} 29^{\prime} \mathrm{N}$; longitude: $128^{\circ} 44^{\prime} \mathrm{E}$; distance from the experimental field: $7.48 \mathrm{~km}$ ).

WFPS (\%) was calculated every day for a year using the following equation:

$$
\text { WFPS }(\%)=(\theta / \text { soil porosity }) \times 100
$$

where $\theta$ is the volumetric moisture content $\left(\mathrm{m}^{3} \cdot \mathrm{m}^{-3}\right)$. Soil porosity $\left(\mathrm{m}^{3} \cdot \mathrm{m}^{-3}\right)$ was calculated using a particle density value of $2.65 \mathrm{~g} \cdot \mathrm{m}^{-3}$ and soil bulk density values. Bulk density was determined using soil samples of all plots collected from a depth of $0-15 \mathrm{~cm}$ once a month during the study period. Samples were collected by a fixed-volume core $\left(94.64 \mathrm{~cm}^{3}\right)$ and dried at $105^{\circ} \mathrm{C}$.

\subsection{Statistical Analysis}

Statistical analysis was performed using R software package V. 3.6.2 (http:/ / www. $\mathrm{R}$-project.org, accessed on12 June 2020). The mean values of cumulative $\mathrm{N}_{2} \mathrm{O}$ emissions, radish and maize yields, and yield-scaled $\mathrm{N}_{2} \mathrm{O}$ emissions were compared using pairwise comparison. Differences among parameters were determined using two-way analysis of variance. Application rate $(\mathrm{R})$ and year $(\mathrm{Y})$ were considered to be fixed effects. Owing to application rate $\times$ year interactions for cumulative $\mathrm{N}_{2} \mathrm{O}$ emission during radish and maize growing seasons, each year was separately analyzed. The least significant difference was used for multiple comparisons between the means and performed only when the F-test result was significant $(p<0.05)$.

\section{Results}

\section{1. $\mathrm{N}_{2} \mathrm{O}$ Flux}

$\mathrm{N}_{2} \mathrm{O}$ flux patterns differed with air temperature patterns over the study period, as shown in Figure 2a,b. Although flux was relatively low during the cold and dry fallow season, it did not peak as air temperature reached its maximum in the August of both Years 1 and 2. $\mathrm{N}_{2} \mathrm{O}$ flux peaks appeared only during the radish and maize growing seasons in Years 1 and 2 when basal and additional $\mathrm{N}$ fertilizers were applied, but peaks did not appear during fallow seasons. More $\mathrm{N}_{2} \mathrm{O}$ flux peaks appeared during the maize growing season than during the radish growing season in Years 1 and 2.

Daily WFPS values varied over 2 years and increased after high rainfall and irrigation events during this period (Figure 2c). BA application rate resulted in a change in soil WFPS values. Daily WFPS values of soil amended with $0 \mathrm{Mg} \cdot \mathrm{ha}^{-1}$ of BA were always the highest, followed by those of soil amended with 200 and $400 \mathrm{Mg} \cdot \mathrm{ha}^{-1}$ of BA over the 2 years. 


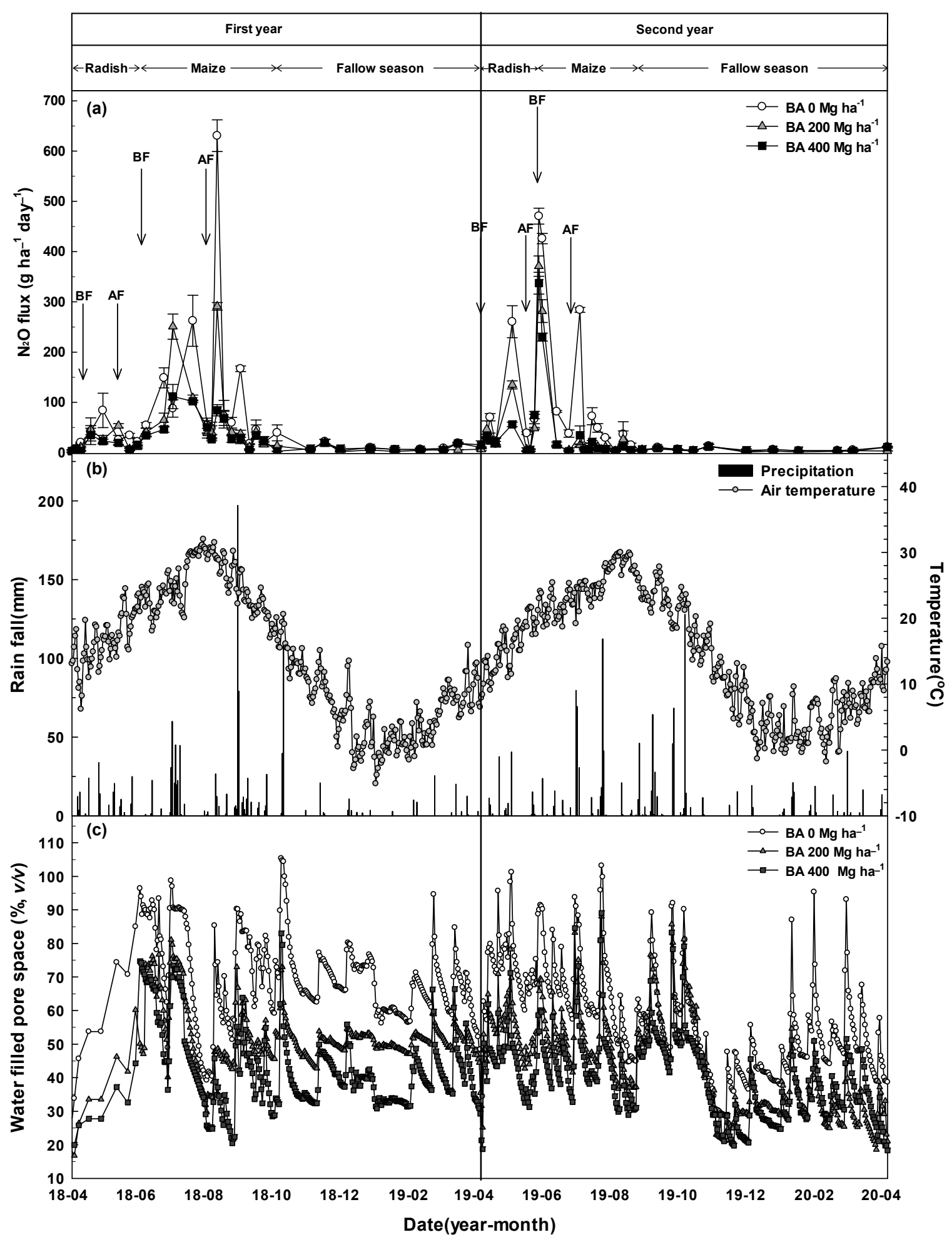

Figure 2. Nitrous oxide flux (a), daily air temperature, precipitation (b), and water-filled pore space (c) after the application of bottom ash at various rates for 2 years. Arrows in the graph represent fertilizer addition and irrigation, and BF and AF denote base and additional fertilizer applications, respectively.

\subsection{Cumulative $\mathrm{N}_{2} \mathrm{O}$ Emission}

There was a significant $\mathrm{R} \times \mathrm{Y}$ interaction for cumulative $\mathrm{N}_{2} \mathrm{O}$ emission during the radish growing season (Table 3). Cumulative $\mathrm{N}_{2} \mathrm{O}$ emission during the radish growing season decreased significantly following application of $400 \mathrm{Mg} \cdot \mathrm{ha}^{-1}$ of BA in Year 1 and with increasing BA application rate in Year 2 (Table 4). 
Table 3. Analysis of variance and probability value of cumulative nitrous oxide $\left(\mathrm{N}_{2} \mathrm{O}\right)$ emissions, chemical and physical properties of soil, and crop yields.

\begin{tabular}{|c|c|c|c|}
\hline Source of Variation & Application Rate (R) & Year $(Y)$ & $\mathbf{R} \times \mathbf{Y}$ \\
\hline Df & 2 & 1 & 2 \\
\hline Cumulative $\mathrm{N}_{2} \mathrm{O}$ emission during radish growing season & $<0.001$ & $<0.001$ & 0.0232 \\
\hline Cumulative $\mathrm{N}_{2} \mathrm{O}$ emission during maize growing season & $<0.001$ & $<0.001$ & 0.0166 \\
\hline Cumulative $\mathrm{N}_{2} \mathrm{O}$ emission during entire year & $<0.001$ & NS & NS \\
\hline Averaged bulk density & $<0.001$ & $<0.001$ & NS \\
\hline Averaged water-filled pore space during radish growing season & $<0.001$ & $<0.001$ & $<0.001$ \\
\hline Averaged water-filled pore space during maize growing season & $<0.001$ & NS & NS \\
\hline Averaged water-filled pore space during entire year & $<0.001$ & NS & NS \\
\hline Soil $\mathrm{pH}$ & $<0.001$ & NS & NS \\
\hline Electrical conductivity & NS & NS & NS \\
\hline Organic matter & NS & $<0.001$ & NS \\
\hline Total nitrogen & NS & $<0.001$ & NS \\
\hline Av. P2O5 & NS & $<0.001$ & NS \\
\hline Exchangeable K & NS & NS & NS \\
\hline Exchangeable Ca & NS & NS & NS \\
\hline Exchangeable $\mathrm{Mg}$ & NS & NS & NS \\
\hline Bulk density & $<0.001$ & $<0.001$ & NS \\
\hline Ammonium $\left(\mathrm{NH}_{4}{ }^{+}\right)$in soil & 0.0224 & $<0.001$ & NS \\
\hline Nitrate $\left(\mathrm{NO}_{3}^{-}\right)$in soil & $<0.001$ & NS & NS \\
\hline Radish yield & NS & $<0.001$ & NS \\
\hline Maize yield * & NS & NS & NS \\
\hline Radish yield-scaled $\mathrm{N}_{2} \mathrm{O}$ emission & $<0.001$ & $<0.001$ & NS \\
\hline Maize yield-scaled $\mathrm{N}_{2} \mathrm{O}$ emission & 0.0015 & NS & NS \\
\hline Total yield-scaled $\mathrm{N}_{2} \mathrm{O}$ emission & $<0.001$ & NS & NS \\
\hline
\end{tabular}

Maize yield *: grain yield of maize. NS: not significant.

Table 4. Cumulative emission of nitrous oxide $\left(\mathrm{N}_{2} \mathrm{O}\right)$ during radish and maize cropping seasons and a year with different rates of bottom-ash application.

\begin{tabular}{|c|c|c|c|c|c|c|c|}
\hline \multirow{2}{*}{$\begin{array}{c}\text { Bottom Ash } \\
\text { Application Rate } \\
\text { (Mg/ha) }\end{array}$} & \multicolumn{2}{|c|}{$\begin{array}{c}\text { Cumulative } \mathrm{N}_{2} \mathrm{O} \text { Emission } \\
\text { during Radish Growing } \\
\text { Season }\left(\mathrm{kg} \cdot \mathrm{ha}^{-1}\right)\end{array}$} & \multicolumn{2}{|c|}{$\begin{array}{c}\text { Cumulative } \mathrm{N}_{2} \mathrm{O} \text { Emission } \\
\text { during Maize Growing } \\
\text { Season }\left(\mathrm{kg} \cdot \mathrm{ha}^{-1}\right)\end{array}$} & \multicolumn{3}{|c|}{$\begin{array}{c}\text { Cumulative } \mathrm{N}_{2} \mathrm{O} \text { Emission during } \\
\text { Entire Year }\left(\mathrm{kg} \cdot \mathrm{ha}^{-1}\right)\end{array}$} \\
\hline & Year 1 & Year 2 & Year 1 & Year 2 & Year 1 & Year 2 & Year Mean \\
\hline 0 & $2.3^{\mathrm{a}}$ & $4.7^{\mathrm{a}}$ & $14.6^{\mathrm{a}}$ & $9.9^{\mathrm{a}}$ & 19.5 & 16.0 & $17.7^{\mathrm{a}}$ \\
\hline 200 & $1.6^{\mathrm{ab}}$ & $2.6^{\mathrm{b}}$ & $9.9^{b}$ & $4.5^{\mathrm{b}}$ & 12.9 & 8.0 & $10.4^{\mathrm{b}}$ \\
\hline 400 & $1.0^{\mathrm{b}}$ & $1.5^{\mathrm{c}}$ & $6.3^{c}$ & $4.0^{\mathrm{b}}$ & 9.2 & 6.9 & $8.0^{\mathrm{c}}$ \\
\hline Rate mean ${ }^{1}$ & & & & & $13.8^{\mathrm{A}}$ & $10.3^{\mathrm{A}}$ & - \\
\hline
\end{tabular}

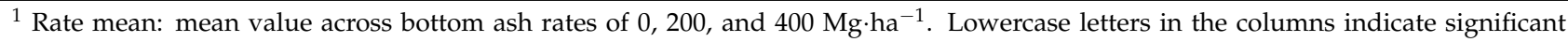
differences at $p<0.05$ for all treatments. Uppercase letters in the rows indicate significant differences at $p<0.05$ between Years 1 and 2.

A significant $\mathrm{R} \times \mathrm{Y}$ interaction was noted for cumulative $\mathrm{N}_{2} \mathrm{O}$ emission during the maize growing season (Table 3). Cumulative $\mathrm{N}_{2} \mathrm{O}$ emission during the maize growing season increased significantly with an increasing BA application rate in Year 1 and with a BA application rate of up to $200 \mathrm{Mg} \cdot \mathrm{ha}^{-1}$ in Year 2 (Table 4).

Application rate, but not year, significantly influenced cumulative $\mathrm{N}_{2} \mathrm{O}$ emission during the entire year (Table 3). The mean value of cumulative $\mathrm{N}_{2} \mathrm{O}$ emission during the entire year across both Years 1 and 2 decreased significantly with increasing BA application rate (Table 4).

\subsection{Changes in the Physical and Chemical Properties of Soil}

Mean WFPS values during the radish growing season, maize growing season, and the entire year for Years 1 and 2 decreased with BA application (Table 5). Mean WFPS values during the radish growing season decreased significantly following application of $200 \mathrm{Mg} \cdot \mathrm{ha}^{-1}$ of BA in Year 1 and with increasing BA application rate in Year 2. Mean 
WFPS values during the maize growing season and the entire year across both Years 1 and 2 decreased significantly following BA application of $200 \mathrm{Mg} \cdot \mathrm{ha}^{-1}$. Mean WFPS values during the maize growing season and entire year across application rates were higher in Year 1 than in Year 2, although there was no significant difference between mean values for both years.

Table 5. Averaged water-filled pore space (WFPS) of soil during radish and maize growing seasons and the entire year with different application rates of bottom ash in Years 1 and 2.

\begin{tabular}{|c|c|c|c|c|c|c|c|c|}
\hline \multirow{2}{*}{$\begin{array}{c}\text { Application } \\
\text { Rate } \\
\left(\mathbf{M g} \cdot \mathbf{h a}^{-1}\right)\end{array}$} & \multicolumn{2}{|c|}{$\begin{array}{l}\text { Averaged WFPS during the } \\
\text { Radish Growing Season (\%) }\end{array}$} & \multicolumn{3}{|c|}{$\begin{array}{c}\text { Averaged WFPS during the Maize } \\
\text { Growing Season (\%) }\end{array}$} & \multicolumn{3}{|c|}{$\begin{array}{c}\text { Averaged WFPS during the Entire } \\
\text { Year (\%) }\end{array}$} \\
\hline & Year 1 & Year 2 & Year 1 & Year 2 & Year Mean & Year 1 & Year 2 & Year Mean \\
\hline 0 & $54.9^{\mathrm{a}}$ & $71.0^{\mathrm{a}}$ & 73.1 & 66.6 & $69.9^{\mathrm{a}}$ & 71.9 & 68.5 & $70.2^{\mathrm{a}}$ \\
\hline 200 & $34.7^{b}$ & $53.0^{\mathrm{b}}$ & 55.0 & 51.6 & $53.3^{\mathrm{b}}$ & 53.6 & 52.3 & $52.9^{b}$ \\
\hline 400 & $29.3^{b}$ & $43.3^{c}$ & 47.3 & 44.7 & $46.0^{\mathrm{b}}$ & 46.1 & 44.5 & $45.3^{b}$ \\
\hline Rate mean ${ }^{1}$ & & - & $58.5^{\mathrm{A}}$ & $54.3^{\mathrm{A}}$ & - & $57.2^{\mathrm{A}}$ & $55.1^{\mathrm{A}}$ & - \\
\hline
\end{tabular}

${ }^{1}$ Rate mean: mean value across application rates of 0,200 , and $400 \mathrm{Mg} \cdot \mathrm{ha}^{-1}$. Lower case letters in the columns indicate significant differences at $p<0.05$ among all treatments. Upper case letters in the rows indicate significant differences at $p<0.05$ between Years 1 and 2 .

The mean value of soil $\mathrm{pH}$ at maize harvest time across both Years 1 and 2 increased significantly with a BA application rate of up to $200 \mathrm{Mg} \cdot \mathrm{ha}^{-1}$, but no further increase was observed with additional BA application (Table 6).

Table 6. Changes in chemical properties of soil amended with different application rates of bottom ash (BA) during maize harvest time.

\begin{tabular}{|c|c|c|c|c|c|c|c|c|c|c|}
\hline \multirow{2}{*}{\multicolumn{2}{|c|}{$\begin{array}{c}\text { BA Application } \\
\text { Rate } \\
\left(\mathrm{Mg} \cdot \mathrm{ha}^{-1}\right)\end{array}$}} & \multirow[t]{2}{*}{$\mathrm{pH}$} & \multirow{2}{*}{$\begin{array}{c}\text { Electrical } \\
\text { Conductivity } \\
(\mathrm{dS} / \mathrm{m})\end{array}$} & \multirow{2}{*}{$\begin{array}{l}\text { Organic } \\
\text { Matter } \\
(\mathrm{g} / \mathrm{kg})\end{array}$} & \multirow{2}{*}{$\begin{array}{c}\text { Total Ni- } \\
\text { trogen } \\
(\mathrm{g} / \mathrm{kg})\end{array}$} & \multirow{2}{*}{$\begin{array}{c}\mathrm{AV} . \\
\mathrm{P}_{2} \mathrm{O}_{5} \\
\text { (mg/kg) }\end{array}$} & \multicolumn{3}{|c|}{$\begin{array}{l}\text { Exchangeable Cations } \\
\quad\left(\mathrm{cmol}_{\mathrm{c}} \cdot \mathrm{kg}^{-1}\right)\end{array}$} & \multirow{2}{*}{$\begin{array}{c}\text { Bulk } \\
\text { Density } \\
\left(\mathrm{g} / \mathrm{cm}^{3}\right)\end{array}$} \\
\hline & & & & & & & $\mathbf{K}$ & $\mathrm{Ca}$ & $\mathrm{Mg}$ & \\
\hline \multirow{3}{*}{$\begin{array}{l}\text { Year } \\
\text { mean }\end{array}$} & 0 & $5.5^{b}$ & $0.6^{\mathrm{a}}$ & $18.8^{a}$ & $1.16^{\mathrm{a}}$ & $277^{a}$ & $0.57^{a}$ & $5.38^{a}$ & $1.77^{\mathrm{a}}$ & $1.17^{\mathrm{a}}$ \\
\hline & 200 & $5.9^{\mathrm{a}}$ & $0.6^{\mathrm{a}}$ & $19.0^{\mathrm{a}}$ & $1.09^{\mathrm{a}}$ & $278^{a}$ & $0.58^{a}$ & $5.47^{\mathrm{a}}$ & $1.82^{\mathrm{a}}$ & $1.04^{b}$ \\
\hline & 400 & $5.8^{\mathrm{a}}$ & $0.7^{\mathrm{a}}$ & $19.9^{a}$ & $1.16^{\mathrm{a}}$ & $285^{\mathrm{a}}$ & $0.58^{a}$ & $5.44^{\mathrm{a}}$ & $1.82^{\mathrm{a}}$ & $1.01^{b}$ \\
\hline
\end{tabular}

Year mean: mean value across Years 1 and 2. Different lower case letters denote significance at $p<0.05$ for comparisons within column.

A trade-off effect was observed between $\mathrm{NO}_{3}{ }^{-}$and $\mathrm{NH}_{4}{ }^{+}$concentrations in the soil during radish and maize growing seasons in both Years 1 and 2 (Figure 3). Soil $\mathrm{NO}_{3}{ }^{-}$concentration increased with decreasing soil $\mathrm{NH}_{4}{ }^{+}$concentration. $\mathrm{NO}_{3}{ }^{-}$and $\mathrm{NH}_{4}{ }^{+}$ concentrations varied during radish and maize growing seasons in Years 1 and 2. However, $\mathrm{NO}_{3}{ }^{-}$concentration in soil amended with $400 \mathrm{Mg} \cdot \mathrm{ha}^{-1}$ of BA was always the highest, followed by that in soil amended with 200 and $0 \mathrm{Mg} \cdot \mathrm{ha}^{-1}$ of BA during the radish and maize growing seasons in Years 1 and 2. Conversely, $\mathrm{NH}_{4}{ }^{+}$concentration in soils amended with $0 \mathrm{Mg} \cdot \mathrm{ha}^{-1}$ of BA was always the highest, followed by that in soil amended with 200 and $400 \mathrm{Mg} \cdot \mathrm{ha}^{-1}$ of BA during the radish and maize growing seasons in both Years 1 and 2. 


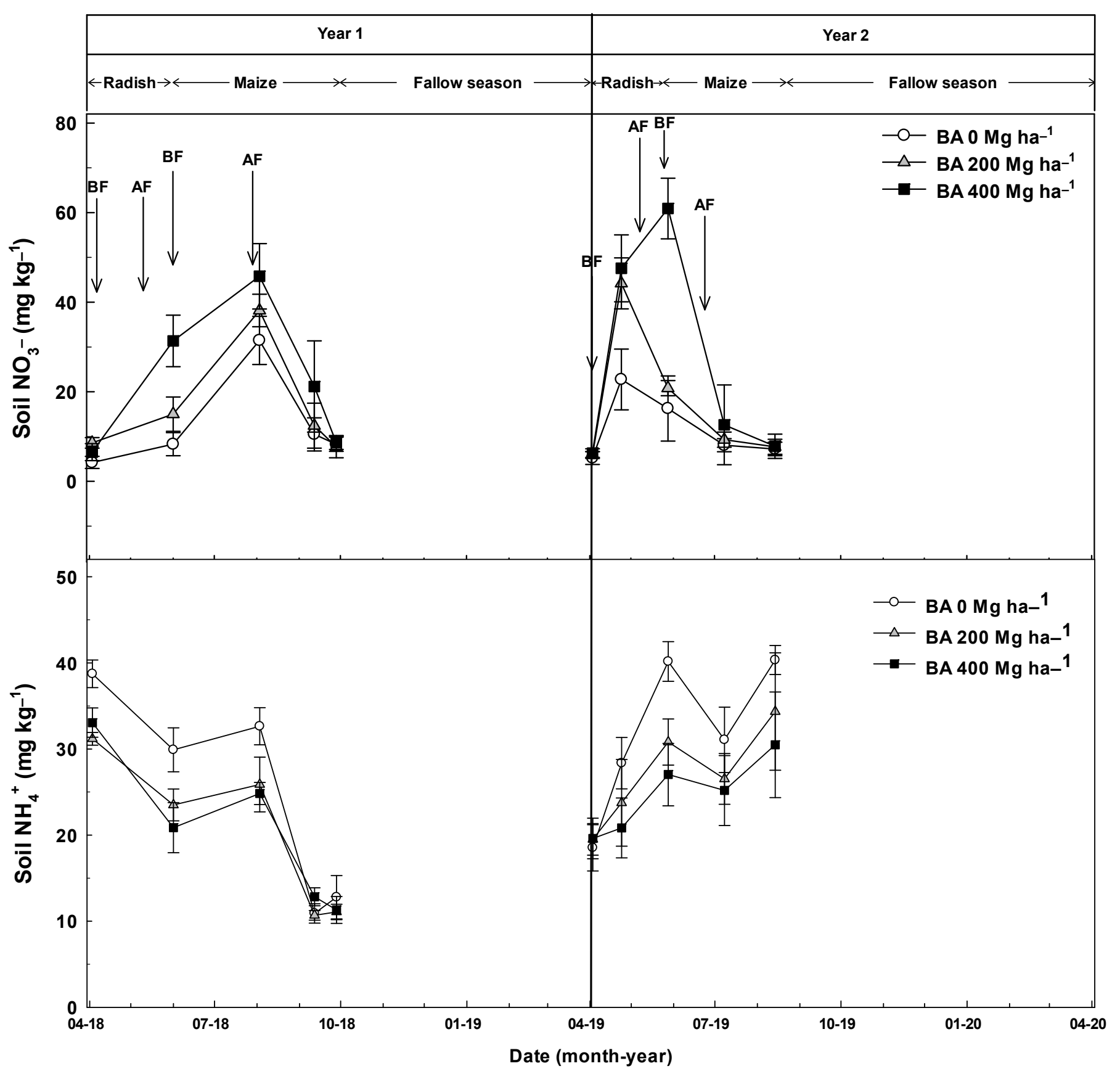

Figure 3. Seasonal changes in nitrate $\left(\mathrm{NO}_{3}{ }^{-}\right)$and ammonium $\left(\mathrm{NH}_{4}{ }^{+}\right)$concentrations in the top $15 \mathrm{~cm}$ soil depth following application of different rates of bottom ash during the radish and maize growing seasons in Years 1 and 2.

\subsection{Crop Yield and Yield-Scaled $\mathrm{N}_{2} \mathrm{O}$ Emission}

BA application rate did not influence radish and maize yields in this study (Tables 3 and 7).

BA application rate significantly influenced yield-scaled $\mathrm{N}_{2} \mathrm{O}$ emissions (Table 3). Radish yield-scaled $\mathrm{N}_{2} \mathrm{O}$ emission decreased significantly with increasing application rates of BA (Table 7). Maize yield-scaled $\mathrm{N}_{2} \mathrm{O}$ emission and total yield-scaled $\mathrm{N}_{2} \mathrm{O}$ emission decreased significantly following a BA application rate of up to $200 \mathrm{Mg} \cdot \mathrm{ha}^{-1}$, but no further decrease was noted with additional BA application. 
Table 7. Biomass yields of radish and maize and yield-scaled nitrous oxide $\left(\mathrm{N}_{2} \mathrm{O}\right)$ emission with different rates of bottom-ash application.

\begin{tabular}{|c|c|c|}
\hline & Bottom Ash Rate (Mg.ha $\left.{ }^{-1}\right)$ & Year Mean \\
\hline \multirow{3}{*}{ Radish yield } & 0 & $1.51^{\mathrm{a}}$ \\
\hline & 200 & $1.43^{\mathrm{a}}$ \\
\hline & 400 & $1.49^{\mathrm{a}}$ \\
\hline \multirow{3}{*}{ Maize yield } & 0 & $5.26^{\mathrm{a}}$ \\
\hline & 200 & $5.35^{\mathrm{a}}$ \\
\hline & 400 & $5.14^{\mathrm{a}}$ \\
\hline \multirow{3}{*}{$\begin{array}{l}\text { Radish yield-scaled } \mathrm{N}_{2} \mathrm{O} \text { emission } \\
\qquad\left(\mathrm{kg} \cdot \mathrm{N}_{2} \mathrm{O} \cdot \mathrm{Mg}^{-1} \text { radish }\right)\end{array}$} & 0 & $3.16^{\mathrm{a}}$ \\
\hline & 200 & $1.90^{\mathrm{b}}$ \\
\hline & 400 & $1.01^{\mathrm{c}}$ \\
\hline \multirow{3}{*}{$\begin{array}{l}\text { Maize yield-scaled } \mathrm{N}_{2} \mathrm{O} \text { emission } \\
\qquad\left(\mathrm{kg} \cdot \mathrm{N}_{2} \mathrm{O} \cdot \mathrm{Mg}^{-1} \text { maize }\right)\end{array}$} & 0 & $2.61^{\mathrm{a}}$ \\
\hline & 200 & $1.41^{\mathrm{b}}$ \\
\hline & 400 & $1.11^{\mathrm{b}}$ \\
\hline \multirow{3}{*}{$\begin{array}{c}\text { Total yield-scaled } \mathrm{N}_{2} \mathrm{O} \text { emissions } \\
\left(\mathrm{kg} \cdot \mathrm{N}_{2} \mathrm{O} \cdot \mathrm{Mg}^{-1} \text { radish }+ \text { maize }\right)\end{array}$} & 0 & $2.49^{\mathrm{a}}$ \\
\hline & 200 & $1.39^{b}$ \\
\hline & 400 & $0.99^{b}$ \\
\hline
\end{tabular}

Year mean: mean value across Years 1 and 2. Different lower case letters denote significance at $p<0.05$ for comparisons among bottom ash rates.

\section{Discussion}

Precipitation affects $\mathrm{N}_{2} \mathrm{O}$ emissions from arable soil. Some studies have reported that $\mathrm{N}_{2} \mathrm{O}$ flux peaked after a high-rainfall event, which led to soil adopting an anoxic state for $\mathrm{N}_{2} \mathrm{O}$ production via denitrification [33-36]. However, in this study, the peak of the $\mathrm{N}_{2} \mathrm{O}$ flux did not appear after high-rainfall events, despite several occurrences of such events over the 2 years. All $\mathrm{N}_{2} \mathrm{O}$ flux peaks appeared only during the radish and maize growing season. The peak of the $\mathrm{N}_{2} \mathrm{O}$ flux did not appear soon after $\mathrm{N}$-fertilizer application, but rather occurred 3-23 days later after urea application. Further, daily $\mathrm{N}_{2} \mathrm{O}$ flux is associated with soil WFPS values. Nitrification is the predominant process for $\mathrm{N}_{2} \mathrm{O}$ emission from soils with $<60 \%$ WFPS, whereas denitrification is the predominant process of $\mathrm{N}_{2} \mathrm{O}$ emission from soil with $>60 \%$ WFPS [10-12]. When soil WFPS value is approximately $60 \%, \mathrm{~N}_{2} \mathrm{O}$ production increases considerably owing to simultaneous nitrification and denitrification [37]. When soil WFPS value increases by $>70 \%$, soil environmental conditions favor denitrification and $\mathrm{N}_{2}$ is emitted instead of $\mathrm{N}_{2} \mathrm{O}$ [13]. In the present study, all $\mathrm{N}_{2} \mathrm{O}$ flux peaks after $\mathrm{N}$-fertilizer application during the growing season in both years appeared when WFPS value was approximately $65 \%$, as shown in Figure 2a,c. For example, the peak of the daily $\mathrm{N}_{2} \mathrm{O}$ flux did not appear following application of $0 \mathrm{Mg} \cdot \mathrm{ha}^{-1}$ of BA on 29 May 2018, when a basal N fertilizer was applied during the maize growing season in Year 1 because daily WFPS value was $86 \%$ on that day. Under these $\mathrm{O}_{2}$-limited conditions, $\mathrm{N}_{2}$ is primarily emitted instead of $\mathrm{N}_{2} \mathrm{O}$. However, the first and second peaks of daily $\mathrm{N}_{2} \mathrm{O}$ flux following application of $0 \mathrm{Mg} \cdot \mathrm{ha}^{-1}$ of BA appeared on 21 June and 17 July after basal $\mathrm{N}$-fertilizer application when daily WFPS values were $66 \%$ and $62 \%$, respectively.

$\mathrm{NO}_{3}{ }^{-}$concentrations in soil increased with increasing BA application rate during radish and maize growing seasons (Figure 3), whereas that of $\mathrm{NH}_{4}{ }^{+}$decreased with increasing BA application rate. This implies that nitrification is the predominant $\mathrm{N}_{2} \mathrm{O}$ producing process rather than denitrification in BA-amended soils as BA application decreases soil WFPS values. A $35 \%-60 \%$ WFPS value constitutes favorable soil water conditions for nitrification. The mean WFPS value during the entire year across Years 1 and 2 decreased from $70.2 \%$ with $0 \mathrm{Mg} \cdot$ ha $^{-1}$ of BA to $52.9 \%$ and $45.3 \%$ with 200 and $400 \mathrm{Mg} \cdot \mathrm{ha}^{-1}$ of BA, respectively (Table 5 ).

As mentioned above, this study examined three hypotheses. The first hypothesis was that the application of porous BA decreases bulk density and WFPS value of soil to 
render soil conditions unfavorable for microorganisms associated with $\mathrm{N}_{2} \mathrm{O}$-production processes, such as nitrification and denitrification. Results from this study confirmed the first hypothesis. The bulk density of soil at maize harvest time decreased significantly following BA application at $200 \mathrm{Mg} \cdot \mathrm{ha}^{-1}$ (Table 6). This decrease in the bulk density of soil following BA application was owing to the physical properties of BA, including its high porosity and large surface area (Table 2). Subsequently, this reduced the WFPS of soil. The mean WFPS value during the entire year across both Years 1 and 2 decreased from $70.2 \%$ following application of $0 \mathrm{Mg} \cdot \mathrm{ha}^{-1}$ of BA up to $45.3 \%$ with $400 \mathrm{Mg} \cdot \mathrm{ha}^{-1}$ of BA (Table 5). Specifically, daily WFPS value with 200 and $400 \mathrm{Mg} \cdot \mathrm{ha}^{-1}$ of BA was mostly below $35 \%$ during the entire year, except for high rainfall and irrigation events, as shown in Figure 2c. A WFPS value of $35-60 \%$ constitutes favorable soil water conditions for nitrification. However, nitrification and denitrification reduced in water-limited conditions involving a WFPS value of $<35 \%[12,38]$. BA application may ensure water-limited conditions for microorganisms involved in nitrification and denitrification and thus decrease $\mathrm{N}_{2} \mathrm{O}$ emission from soil. Similar results with this study were observed by other researchers using ash materials, such as biochar and charcoal. Carvalho et al. [39] reported that WFPS value decreased significantly by approximately $10 \%$ following the application of $32 \mathrm{Mg} \cdot \mathrm{ha}^{-1}$ of wood biochar in a bean-rice rotated cultivation system. They observed a positive correlation between $\mathrm{N}_{2} \mathrm{O}$ fluxes and WFPS value, indicating that WFPS was a relevant soil variable related to $\mathrm{N}_{2} \mathrm{O}$ emission. In addition, Yanai et al. [40] reported that suppressed $\mathrm{N}_{2} \mathrm{O}$ emissions after adding charcoal stemmed from changes in WFPS values rather than the addition of $\mathrm{Cl}^{-}$and $\mathrm{SO}_{4}{ }^{2-}$, which were the major anions in charcoal based on laboratory experiments. In the current study, a large decrease in WFPS value (from $70.2 \%$ to $45.3 \%$ ) with BA application was observed compared with the results of other studies $[39,40]$, owing to a greater BA application rate $\left(400 \mathrm{Mg} \cdot \mathrm{ha}^{-1}\right)$. Therefore, we observed a further decrease in cumulative $\mathrm{N}_{2} \mathrm{O}$ emission by up to $54.8 \%$, i.e., from $17.7 \mathrm{~kg} \cdot \mathrm{N}_{2} \mathrm{O} \cdot \mathrm{ha}^{-1}$ to $8.0 \mathrm{~kg} \cdot \mathrm{N}_{2} \mathrm{O} \cdot \mathrm{ha}^{-1}$.

The second hypothesis was that alkaline $\mathrm{BA}$ application increases soil $\mathrm{pH}$, promotes reduction of $\mathrm{N}_{2} \mathrm{O}$ to $\mathrm{N}_{2}$, and decreases $\mathrm{N}_{2} \mathrm{O}$ emission. Soil $\mathrm{pH}$ increased following $\mathrm{BA}$ application (Table 6) owing to the chemical properties of BA such as presence of large amounts of $\mathrm{CaCO}_{3}$ and $\mathrm{CaO}$ (Table 2). Soil $\mathrm{pH}$ is a primary factor influencing $\mathrm{N}_{2} \mathrm{O}$ production and consumption processes in soil [41,42]. Several studies have reported that the abundance of nitrogen-cycling genes and the rates of nitrification and denitrification are strongly regulated by soil $\mathrm{pH}$ [43-46]. Notably, Nos activity is more sensitive to low $\mathrm{pH}$ than other reductases in denitrification [47]. Therefore, under low soil $\mathrm{pH}$ conditions, more $\mathrm{N}_{2} \mathrm{O}$ is produced than $\mathrm{N}_{2}$ [48]. The ratios of $\mathrm{N}_{2} \mathrm{O} /\left(\mathrm{N}_{2}+\mathrm{N}_{2} \mathrm{O}\right)$ showed a significant negative correlation with soil $\mathrm{pH}$ within the generally observed $\mathrm{pH}$ range of 5-8 in agricultural soils [45,48]. Increasing $\mathrm{pH}$ of acidic soil decreases $\mathrm{N}_{2} \mathrm{O}$ emissions from nitrification by increasing ammonia oxidizing bacteria (AOB) gene copy numbers [49]. In this study, soil $\mathrm{pH}$ increased from 5.4 at $0 \mathrm{Mg} \cdot \mathrm{ha}^{-1}$ of BA up to 5.9 following application of 200 $\mathrm{Mg} \cdot \mathrm{ha}^{-1}$ of BA (Table 6). Therefore, an increase in soil $\mathrm{pH}$ with BA application may help reduce $\mathrm{N}_{2} \mathrm{O}$ emission from the soil by decreasing $A O B$ abundance during nitrification and increasing Nos activity during denitrification. Kim et al. [21] reported that soil $\mathrm{pH}$ increased from 6.03 to 6.16 with $30 \mathrm{Mg} \cdot \mathrm{ha}^{-1}$ of BA application in upland soil used for growing lettuce. In the current study, a greater increase in soil $\mathrm{pH}$ (from 5.4 to 5.9) with BA application was observed compared with their results as a higher BA rate $\left(200 \mathrm{Mg} \cdot \mathrm{ha}^{-1}\right)$ was applied. Some studies have reported that liming affects acidic soil by suppressing $\mathrm{N}_{2} \mathrm{O}$ emissions. Shaaban et al. [50] observed that soil $\mathrm{pH}$ of two acidic soils (5.25 and 5.52) significantly increased by 7.62 and 7.77 after adding $15 \mathrm{~g} \cdot \mathrm{kg}^{-1}$ of dolomite $\left[\mathrm{CaMg}\left(\mathrm{CO}_{3}\right)_{2}\right]$ and cumulative $\mathrm{N}_{2} \mathrm{O}$ emissions decreased by up to $73.77 \%$ and $64.07 \%$ compared with the control, respectively. Barton et al. [49] also reported that increasing soil $\mathrm{pH}$ from 4.21 to 6.34 by liming decreased cumulative $\mathrm{N}_{2} \mathrm{O}$ emission by $16.3 \%$, i.e., from $1.66 \mathrm{mg} \mathrm{N}_{2} \mathrm{O}^{-} \mathrm{N} \mathrm{kg}^{-1}$ to $1.39 \mathrm{mg} \mathrm{N}_{2} \mathrm{O}^{-} \mathrm{N} \mathrm{kg}^{-1}$. 
The third hypothesis was that BA comprising various elements provides available nutrients for plant growth and increases crop yield. However, this hypothesis was not confirmed based on our results. Radish and maize yields did not increase with increasing BA application rate. Rather, BA application decreased bulk density and WFPS value of soil in the present study (Tables 5 and 6), implying improved physical properties, such as porosity and aeration. However, several studies have reported that crop yield was not influenced by changes in physical soil properties for a short period of $<5$ years [51-54]. This study was conducted for a short period of 2 years. Improved crop yield through changes in physical properties of soil via BA application may have been observed for a study period of $>5$ years. In addition, macronutrient concentration, such as total nitrogen, available phosphate, and exchangeable $\mathrm{K}$ and $\mathrm{Ca}$ in soil for plant growth, did not increase with increasing BA application rates. However, BA used in this study comprised nitrogen, phosphorus, $\mathrm{CaCO}_{3}$, and $\mathrm{CaO}$ (Tables 2 and 6). We assumed that the low solubility of $\mathrm{BA}$ in the soil did not enrich the soil with sufficient plant nutrients to increase radish and maize yields.

In this study, daily $\mathrm{N}_{2} \mathrm{O}$ fluxes were measured using a static chamber without growing any plants, including radish, maize, and weeds, for the entire experiment period. This may incorrectly reflect the cumulative $\mathrm{N}_{2} \mathrm{O}$ emission from the real crop cultivation system because the effect of rhizosphere soil on $\mathrm{N}_{2} \mathrm{O}$ emission was excluded. Rhizosphere soil encompasses the narrow zone of contact between the roots and soil particles and plays an important role for both plant growth and $\mathrm{N}_{2} \mathrm{O}$ emissions [55,56]. Rapid nitrogen transformations and translocations occur in the rhizosphere soil via root uptake and microbial activities mainly from roots and microorganisms interacting and competing with each other for nutrients [57]. Plant roots directly capture $\mathrm{NH}_{4}{ }^{+}, \mathrm{NO}_{3}{ }^{-}$, and amino acids according to their growth demands while excreting sugars, organic acids, and amino acids, which stimulate microbial growth and influence carbon and the nitrogen biogeochemical cycles. Despite the importance of the rhizosphere and its management for developing effective mitigation strategies, studies quantifying $\mathrm{N}_{2} \mathrm{O}$ emission in the rhizosphere are surprisingly scarce owing to the lack of appropriate tools for performing measurements in such microenvironments. Measuring $\mathrm{N}_{2} \mathrm{O}$ emission in microenvironments remains challenging owing to soil heterogeneity and the gaseous nature of $\mathrm{N}_{2} \mathrm{O}[58,59]$.

Agricultural practices can be associated with $\mathrm{N}_{2} \mathrm{O}$ emission by estimating cumulative $\mathrm{N}_{2} \mathrm{O}$ emission based on crop yield, which are referred to as yield-scaled $\mathrm{N}_{2} \mathrm{O}$ emission. From global environment and food security perspectives, sustainable agriculture in the future should explore systems with low $\mathrm{N}_{2} \mathrm{O}$ emissions and high crop yield to ensure food security. Yield-scaled $\mathrm{N}_{2} \mathrm{O}$ emission provides essential information for estimating the environmental impacts of intensive agricultural production systems [60]. The mean value of total yield-scaled $\mathrm{N}_{2} \mathrm{O}$ emission across both Years 1 and 2 decreased significantly following BA application at $200 \mathrm{Mg} \cdot \mathrm{ha}^{-1}$ and no further decrease was observed after additional BA application (Table 7). A lower value of yield-scaled $\mathrm{N}_{2} \mathrm{O}$ emission indicates less $\mathrm{N}_{2} \mathrm{O}$ emission for the same unit of crop production. Therefore, applications of up to $200 \mathrm{Mg} \cdot \mathrm{ha}^{-1}$ of BA may be environmentally and economically beneficial in soil management to reduce $\mathrm{N}_{2} \mathrm{O}$ emissions while maintaining crop production.

\section{Conclusions}

BA application significantly decreased cumulative $\mathrm{N}_{2} \mathrm{O}$ emission, but did not increase crop yield. BA application of up to $200 \mathrm{Mg} \cdot \mathrm{ha}^{-1}$ significantly decreased yield-scaled $\mathrm{N}_{2} \mathrm{O}$. Mitigating $\mathrm{N}_{2} \mathrm{O}$ emission with BA application was mainly attributed to reduced soil WFPS value and increasing soil $\mathrm{pH}$. For economic viability and environmental conservation, we recommend a BA application rate of $200 \mathrm{Mg} \cdot \mathrm{ha}^{-1}$ to reduce $\mathrm{N}_{2} \mathrm{O}$ emissions per unit of crop production.

Author Contributions: Conceptualization, D.-Y.H., S.-U.K. and C.-O.H.; methodology, D.-Y.H.; software, S.-U.K.; validation, D.-Y.H., S.-U.K. and C.-O.H.; formal analysis, D.-Y.H. and S.-U.K.; investigation, D.-Y.H. and S.-U.K.; resources, D.-Y.H.; data curation, D.-Y.H.; writing-original 
draft preparation, D.-Y.H.; writing-review and editing, S.-U.K. and C.-O.H.; visualization, S.-U.K.; supervision, H.-C.P., K.-K.K., H.-J.S., K.-M.L., Y.-J.K. and C.-O.H.; project administration, D.-Y.H.; funding acquisition, C.-O.H. All authors have read and agreed to the published version of the manuscript.

Funding: This research received no external funding.

Institutional Review Board Statement: Not applicable.

Informed Consent Statement: Not applicable.

Acknowledgments: This work was supported by a 2-Year Research Grant of Pusan National University.

Conflicts of Interest: The authors declare no conflict of interest.

\section{References}

1. World Meteorological Organization (WMO). WMO Greenhouse Gas Bulletin: The State of Greenhouse Gases in the Atmosphere Based on Global Observations through 2018; WMO: Geneva, Switzerland, 2019; p. 15.

2. Intergovernmental Panel on Climate Change (IPCC). 2019 Refinement to the 2006 IPCC Guidelines for National Greenhouse Gas Inventories; Core Writing Team, Calvo, E., Guendehou, S., Limmeechokchai, B., Pipatti, R., Rojas, Y., Sturgiss, R., Tanabe, K., Wirth, T., Eds.; IPCC: Geneva, Switzerland, 2019; Volume 5, p. 194.

3. Lam, S.K.; Suter, H.; Mosier, A.R.; Chen, D. Using nitrification inhibitors to mitigate agricultural $\mathrm{N}_{2} \mathrm{O}$ emission: A double-edged sword? Glob. Change Biol. 2016, 23, 485-489. [CrossRef]

4. Butterbach-Bahl, K.; Baggs, E.M.; Dannenmann, M.; Kiese, R.; Zechmeister-Boltenstern, S. Nitrous oxide emissions from soils: How well do we understand the processes and their controls? Philos. Trans. R. Soc. Lond. B 2017, 368, 1-13. [CrossRef] [PubMed]

5. Westphal, M.; Tenuta, M.; Entz, M.H. Nitrous oxide emissions with organic crop production depends on fall soil moisture. Agric. Ecosyst. Environ. 2018, 254, 41-49. [CrossRef]

6. Shen, J.P.; Zhang, L.M.; Di, H.J.; He, J.Z. A review of ammonia-oxidizing bacteria and archaea in Chinese soils. Front. Microbiol. 2012, 3, 296. [CrossRef] [PubMed]

7. Hu, J.; Inglett, K.S.; Clark, M.W.; Inglett, P.W.; Reddy, K.R. Nitrous oxide production and consumption by denitrification in a grassland: Effects of grazing and hydrology. Sci. Total Environ. 2015, 532, 702-710. [CrossRef] [PubMed]

8. Gregorutti, V.C.; Caviglia, O.P. Nitrous oxide emission after the addition of organic residues on soil surface. Agric. Ecosyst. Environ. 2017, 246, 234-242. [CrossRef]

9. Kuang, W.; Gao, X.; Gui, D.; Tenuta, M.; Flaten, D.N.; Yin, M.; Zeng, F. Effects of fertilizer and irrigation management on nitrous oxide emission from cotton fields in an extremely arid region of northwestern China. Field Crops Res. 2018, 229, 17-26. [CrossRef]

10. Dobbie, K.E.; Smith, K.A. The effects of temperature, water-filled pore space and land use on $\mathrm{N}_{2} \mathrm{O}$ emissions from an imperfectly drained gleysol. Eur. J. Soil Sci. 2001, 52, 667-673. [CrossRef]

11. Dobbie, K.E.; Smith, K.A. $\mathrm{N}_{2} \mathrm{O}$ emission factors for agricultural soils in Great Britain: The impact of soil water-filled pore space and other controlling variables. Glob. Chang. Biol. 2003, 9, 204-218. [CrossRef]

12. Bateman, E.J.; Baggs, E.M. Contribution of nitrification and denitrification to $\mathrm{N}_{2} \mathrm{O}$ emissions from soils at different water-filled pore space. Biol. Fertil. Soils 2005, 41,379-388. [CrossRef]

13. Ruangcharus, C.; Kim, S.U.; Yoo, G.Y.; Choi, E.J.; Kumar, S.; Kang, N.G.; Hong, C.O. Nitrous oxide emission and sweet potato yield in upland soil: Effects of different type and application rate of composted animal manures. Environ. Pollut. 2021, $279,116892$. [CrossRef]

14. Žurovec, O.; Wall, D.P.; Brennan, F.P.; Krol, D.J.; Forrestal, P.J.; Richards, K.G. Increasing soil pH reduces fertiliser derived $\mathrm{N}_{2} \mathrm{O}$ emissions in intensively managed temperate grassland. Agric. Ecosyst. Environ. 2021, 311, 107319. [CrossRef]

15. Russenes, A.L.; Korsaeth, A.; Bakken, L.R.; Dorsch, P. Spatial variation in soil pH controls off-season $\mathrm{N}_{2} \mathrm{O}$ emission in an agricultural soil. Soil Biol. Biochem. 2016, 99, 36-46. [CrossRef]

16. Hu, J.; Inglett, K.S.; Wright, A.L.; Clark, M.W.; Reddy, K.R. Nitrous oxide dynamics during denitrification along a hydrological gradient of subtropical grasslands. Soil Use Manag. 2020, 36, 682-692. [CrossRef]

17. Liu, B.; Frostegård, Å.; Bakken, L.R. Impaired reduction of $\mathrm{N}_{2} \mathrm{O}$ to $\mathrm{N}_{2}$ in acid soils is due to a posttranscriptional interference with the expression of nosZ. mBio 2014, 5, e01383-14. [CrossRef] [PubMed]

18. Maeng, J.H.; Kim, T.Y.; Cho, H.N.; Kim, E.Y. Minimizing environmental impact of ash treatment in thermal power plants (II). Kor. Environ. Inst. 2015, 1, 4-12.

19. Park, S.B.; Jang, Y.I.; Lee, J.; Lee, B.J. An experimental study on the hazard assessment and mechanical properties of porous concrete utilizing coal bottom ash coarse aggregate in Korea. J. Hazard. Mater. 2009, 166, 348-355. [CrossRef]

20. Chindaprasirt, P.; Jaturapitakkul, C.; Chalee, W.; Rattanasak, U. Comparative study on the characteristics of fly ash and bottom ash geopolymers. Waste Manag. 2009, 29, 539-543. [CrossRef]

21. Kim, S.U.; Owens, V.N.; Kim, S.Y.; Hong, C.O. Effect of different way of bottom ash and compost application on phytoextractability of cadmium in contaminated arable soil. Appl. Biol. Chem. 2017, 60, 353-362. [CrossRef] 
22. Argriz, C.; Menéndez, E.; Sanjuán, M.A. Effect of mixes made of coal bottom ash and fly ash on the mechanical strength and porosity of Portland cement. Mater. Construc. 2013, 63, 49-64.

23. Albuquerque, A.R.L.; Angelica, R.S.; Merino, A.; Paz, S.P.A. Chemical and mineralogical characterization and potential use of ash from Amazonian biomasses as an agricultural fertilizer and for soil amendment. J. Clean. Prod. 2021, 295, 126472. [CrossRef]

24. Phan, N.T.; Sengsingkham, T.; Tiyayon, P.; Maneeintr, K. Utilization of bottom ash for degraded soil improvement for sustainable technology. In IOP Conference Series: Earth and Environmental Science; IOP Publishing: Bristol, UK, 2019; Volume 268, p. 012043.

25. Maneeintr, K.; Tran, T.T.A.; Kaewmaneewan, W. Bottom ash waste management for soil improvement in Saraburi Province, Thailand. Mater. Sci. Forum 2019, 947, 114-118. [CrossRef]

26. Kuraz, F.; Alebachew, H.; Sahu, O. Fertibility effect of eucalyptus bottom wood ash on yield and yield components of maize (Zea mays) Ethiopia. J. Adv. Res. Agri. Sci. Tech. 2020, 3, 5-12.

27. Conen, F.; Smith, K.A. A re-examination of closed flux chamber methods for the measurement of trace gas emissions from soils to the atmosphere. Eur. J. Soil Sci. 1998, 49, 701-707. [CrossRef]

28. Venterea, R.T.; Bijesh, M.; Dolan, M.S. Fertilizer Source and tillage effects on yield-scaled nitrous oxide emissions in a corn cropping system. J. Environ. Qual. 2011, 40, 1521-1531. [CrossRef]

29. Allison, L.; Bollen, W.B.; Moodie, C.D. Total carbon. In Methods of Soil Analysis, Part 2; Agronomy Monographs 9; ASA: Madison, WI, USA, 1965; pp. 1346-1366.

30. Cox, M.S. The lancaster soil test method as an alternative to the mehlich 3 soil test metho. Soil Sci. 2001, 166, 484-489. [CrossRef]

31. Searle, P.L. The berthlot or indophenol reaction and its use in the analysis chemistry of nitrogen. Analyst 1984, 109, 549-565. [CrossRef]

32. Wolf, B. Determination of nitrate, nitrite, and ammonium nitrogen rapid photometric determination in soil and plant extracts. Ind. Eng. Chem. Anal. Ed. 1944, 16, 446-447. [CrossRef]

33. Abed, R.M.M.; Lam, P.; de Beer, D.; Stief, P. High rates of denitrification and nitrous oxide emission in arid biological soil crusts from the Sultanate of Oman. ISME J. 2013, 7, 1862-1875. [CrossRef]

34. Hu, J.; VanZomeren, C.M.; Inglett, K.S.; Wright, A.L.; Clark, M.W.; Reddy, K.R. Greenhouse gas emissions under different drainage and flooding regimes of cultivated peatlands. J. Geophys. Res. Biogeo. 2017, 122, 3047-3062. [CrossRef]

35. Kim, D.G.; Mishurov, M.; Kiely, G. Effect of increased $\mathrm{N}$ use and dry periods on $\mathrm{N}_{2} \mathrm{O}$ emission from a fertilized grassland. Nutri. Cycl. Agroecosyst. 2010, 88, 397-410. [CrossRef]

36. Hu, J.; Liao, X.; Vardanyan, L.G.; Huang, Y.; Inglett, K.S.; Wright, A.L.; Reddy, K.R. Duration and frequency of drainage and flooding events interactively affect soil biogeochemistry and $\mathrm{N}$ flux in subtropical peat soils. Sci. Total Environ. 2020, 727, 138740. [CrossRef]

37. Hall, S.J.; Matson, P.A.; Roth, P.M. $\mathrm{NO}_{\mathrm{x}}$ Emissions from soil: Implications for air quality modeling in agricultural regions. Annu. Rev. Energy Environ. 1996, 21, 311-346. [CrossRef]

38. Pihlati, M.; Syvasalo, E.; Simojoki, A.; Esala, M.; Regina, K. Contribution of nitrification and denitrification to $\mathrm{N}_{2} \mathrm{O}$ production in peat, clay and loamy sand soils under different soil moisture conditions. Nutr. Cycl. Agroecosyst. 2004, 70, 135-141. [CrossRef]

39. Carvalho, M.T.M.; Madari, B.E.; Bastiaans, L.; Oort, P.A.J.; Leal, W.G.O.; Souza, D.M.; Santos, R.C.; Matsushige, I.; Maia, A.H.N.; Heinemann, A.B.; et al. Nitrogen availability, water-filled pore space, and $\mathrm{N}_{2} \mathrm{O}-\mathrm{N}$ fluxes after biochar application and nitrogen fertilization. Pesq. Agropec. Bras. 2016, 51, 1203-1212. [CrossRef]

40. Yanai, Y.; Toyota, K.; Okazaki, M. Effects of charcoal addition on $\mathrm{N}_{2} \mathrm{O}$ emissions from soil resulting from rewetting air-dried soil in short-term laboratory experiments. Soil Sci. Plant Nutr. 2007, 53, 181-188. [CrossRef]

41. Cayuela, M.L.; Sanchez-Monedero, M.A.; Roig, A.; Hanley, K.; Enders, A.; Lehmann, J. Biochar and denitrification in soils: When, how much and why does biochar reduce $\mathrm{N}_{2} \mathrm{O}$ emissions? Sci. Rep. 2013, 3, 1732. [CrossRef] [PubMed]

42. Hu, J.; Inglett, K.S.; Wright, A.L.; Reddy, K.R. Nitrous Oxide Production and Reduction in Seasonally-Flooded Cultivated Peatland Soils. Soil Sci. Soc. Am. J. 2016, 80, 783. [CrossRef]

43. He, J.Z.; Shen, J.P.; Zhang, L.M.; Zhu, Y.G.; Zheng, Y.M.; Xu, M.G.; Di, H. Quantitative analyses of the abundance and composition of ammonia-oxidizing bacteria and ammonia-oxidizing archaea of a Chinese upland red soil under long-term fertilization practices. Environ. Microbiol. 2007, 9, 2364-2374. [CrossRef]

44. Shen, J.; Treu, R.; Wang, J.; Nicholson, F.; Bhogal, A.; Thorman, R. Modeling nitrous oxide emissions from digestate and slurry applied to three agricultural soils in the United Kingdom: Fluxes and emission factors. Environ. Pollut. 2018, 243, 1952-1965. [CrossRef]

45. Bakken, L.R.; Bergaust, L.; Liu, B.; Frostegård, A. Regulation of denitrification at the cellular level: A clue to the understanding of $\mathrm{N}_{2} \mathrm{O}$ emissions from soils. Philos. Trans. R. Soc. Lond. B Biol. Sci. 2012, 367, 1226-1234. [CrossRef] [PubMed]

46. Hu, H.W.; Zhang, L.M.; Dai, Y.; Di, H.J.; He, J.Z. pH-dependent distribution of soil ammonia oxidizers across a large geographical scale as revealed by high-throughput pyrosequencing. J. Soils Sediments 2013, 13, 1439-1449. [CrossRef]

47. Sylvia, D.M.; Hartel, P.G.; Fuhrmann, J.J.; Zubber, D.A. Principles and Applications of Soil Microbiology, 2nd ed.; Pearson Education, Inc.: London, UK, 2005.

48. Chapuis-Lardy, L.; Wrage, N.; Metay, A.; Chotte, J.L.; Bernoux, M. Soils, a sink for $\mathrm{N}_{2} \mathrm{O}$ ? A review. Glob. Change Biol. 2007, $13,1-17$. [CrossRef]

49. Barton, L.; Gleeson, D.B.; Maccarone, L.D.; Zúñiga, L.P.; Murphy, D.V. Is liming soil a strategy for mitigating nitrous oxide emissions from semi-arid soils? Soil Biol. Biochem. 2013, 62, 28-35. [CrossRef] 
50. Shaaban, M.; Peng, Q.; Lin, S.; Wu, Y.; Zhao, J.; Hu, R. Nitrous oxide emission from two acidic soils as affected by dolomite application. Soil Res. 2014, 52, 841-848. [CrossRef]

51. Cárcer, P.S.; Sinaj, S.; Santonja, M.; Fossati, D.; Jeangros, B. Long-term effects of crop succession, soil tillage and climate on wheat yield and soil properties. Soil Tillage Res. 2019, 190, 209-219. [CrossRef]

52. Büchi, L.; Wendling, M.; Amossé, C.; Jeangros, B.; Sinaj, S.; Charles, R. Long and short term changes in crop yield and soil properties induced by the reduction of soil tillage in a long term experiment in Switzerland. Soil Tillage Res. 2017, 174, 120-129. [CrossRef]

53. Pittelkow, C.M.; Liang, X.; Linquist, B.A.; van Groenigen, K.J.; Lee, J.; Lundy, M.E.; van Gestel, N.; Six, J.; Venterea, R.T.; van Kessel, C. Productivity limits and potentials of the principles of conservation agriculture. Nature 2015, 517, 365-368. [CrossRef]

54. Pittelkow, C.M.; Linquist, B.A.; Lundy, M.E.; Liang, X.; van Groenigen, K.J.; Lee, J.; van Gestel, N.; Six, J.; Venterea, R.T.; van Kessel, C. When does no-till yield more? global meta-analysis. Field Crops Res. 2015, 183, 156-168. [CrossRef]

55. Geisseler, D.; Horwath, W.R.; Joergensen, R.G.; Ludwig, B. Pathways of nitrogen utilization by soil microorganisms-A review. Soil Biol. Biochem. 2011, 42, 2058-2067. [CrossRef]

56. Kuzyakov, Y. Priming effects: Interactions between living and dead organic matter. Soil Biol. Biochem. 2010, 42, 1363-1371. [CrossRef]

57. Dotaniya, M.L.; Meena, V.D. Rhizosphere effect on nutrient availability in soil and its uptake by plants: A review. Proc. Natl. Acad. Sci. Ind. Sect. B Biol. Sci. 2014, 85, 1-12. [CrossRef]

58. Giuseppe, B.; Ruisi, P.; Rees, R.M. An assessment of factors controlling $\mathrm{N}_{2} \mathrm{O}$ and $\mathrm{CO}_{2}$ emissions from crop residues using different measurement approaches. Biol. Fertil. Soils 2017, 53, 547-561.

59. Markfoged, R.; Nielsen, L.P.; Nyord, T.; Ottosen, L.D.M.; Revsbech, N.P. Transient $\mathrm{N}_{2} \mathrm{O}$ accumulation and emission caused by $\mathrm{O}_{2}$ depletion in soil after liquid manure injection. Eur. J. Soil Sci. 2011, 62, 541-550. [CrossRef]

60. Qin, S.; Wang, Y.; Hu, C.; Oenema, O.; Li, X.; Zhang, Y.; Dong, W. Yield-scaled $\mathrm{N}_{2} \mathrm{O}$ emissions in a winter wheat-summer corn double-cropping system. Atmos. Environ. 2012, 55, 240-244. [CrossRef] 